\title{
THE PLACE OF LOCAL GOVERNMENT IN INTERGOVERNMENTAL RELATIONS: SOUTH AFRICA AND NIGERIA IN COMPARATIVE PERSPECTIVE
}

\author{
Jacob Olufemi Fatile ${ }^{*} \&$ Kehinde David Adejuwon ${ }^{* *}$
}

\begin{abstract}
The main objective of the paper is to examine the place of local government in intergovernmental relations with particular reference to South Africa and Nigeria. The paper adopts the qualitative research approach. It draws its arguments basically from secondary data including existing legal frameworks and other related policies, textbooks, journals articles and other publications. The paper notes that in either a unitary or federal polity, local government serves as incubators for experimental policies which can be reproduced at the national level. This is premised on the idea that it is the level of government that is better placed to effectively formulate and implement development policies and programmes that can efficiently solve problems of service delivery at local level. However, this idea seems defeated by the nature of intergovernmental relations in most developing societies. The paper observes that the nature of intergovernmental relations in Nigeria has over the years eroded the powers and functions of local government administration and has subsequently relegated this level of government to a subsidiary or an appendage of the state and central governments while there is cooperation between local, provincial and national governments in South Africa. The paper notes that while local government in South Africa enjoy autonomy to a certain extent, local governments in Nigeria are not enjoying true autonomous status as a result of excessive interference from other levels of government. The paper recommends among others that there is an urgent need to devolve more responsibility and autonomy to local government authorities through a constitutional amendment to enable them to function effectively and efficiently. It concludes that local governments in South Africa and Nigeria have crucial roles to play in the developmental process provided there is the peaceful atmosphere and adequate autonomy through harmonious intergovernmental relations among various levels of government.
\end{abstract}

INTRODUCTION.

\footnotetext{
* Jacob Olufemi Fatile, Department of Public Administration, Faculty of Management Sciences, Lagos State University, Lagos, Nigeria. Research fields: Collaborative Governance, Intergovernmental Relations and Local Government.

** Kehinde David Adejuwon, Department of Public Administration, Faculty of Management Sciences, Lagos State University, Lagos, Nigeria. Research fields: Intergovernmental Relations, Governance and Development Studies.
} 
I. LOCAL GOVERNMENT AND INTERGOVERNMENTAL RELATIONS:

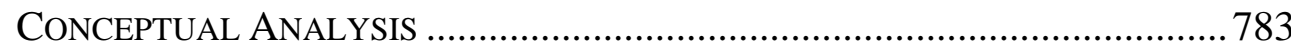

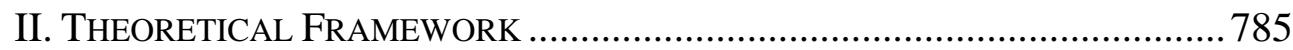

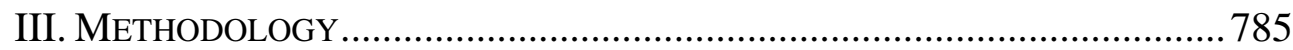

IV. THE NATURE OF INTERGOVERNMENTAL RELATIONS IN SOUTH AFRICA785

V. LOCAL GOVERNMENTS AND IGRS IN SOUTH AFRICA..............................787

VI. AN OVERVIEW OF INTERGOVERNMENTAL RELATIONS IN NIGERIA ........789

VII. LOCAL GOVERNMENTS AND IGRS IN NIGERIA .....................................790

VIII. NATURE AND PATTERN OF INTERGOVERNMENTAL RELATIONS IN SOUTH

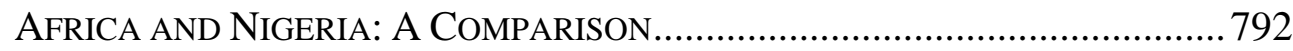

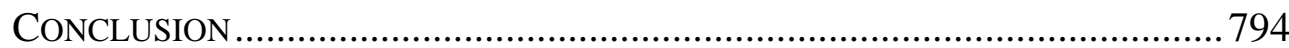

\section{INTRODUCTION}

Intergovernmental relations have received apt attention from scholars over time in the world over. This attention becomes imperative as there are increasing levels of interaction among the different tiers of government in every country. The reality is that interactions occur among them for administrative convenience in realising governmental objectives ${ }^{1}$.

The study of inter-government relations (IGR) presents a dynamic and complex discourse aimed at understanding political and administrative power dimensions and distribution between different tiers, spheres or levels of government. IGR reflects the horizontal and vertical power dynamics between central, state/provincial/regional and local governments and the consequences of this relationship on the degree of autonomy and discretion that sub-national government tiers enjoy from central government control and direction. ${ }^{2}$ The purpose of intergovernmental relations, therefore, either on the national, state or provincial level, is to promote co-operation, coexistence, friendship and détente between governments. ${ }^{3}$

The rationale for intergovernmental relations either in a federal or unitary system has been observed by the founding fathers of American federalism, notably Alexander Hamilton and James Madison in early $1788 .{ }^{4}$

\footnotetext{
${ }^{1}$ E. O. Oni, Intergovernmental Fiscal Relations in Nigeria's Fourth Republic: Issues and Challenges, 1(2) Covenant University Journal of Politics AND International AFFairs 213-234 (2013).

${ }^{2} \mathrm{~V}$. Chakunda, Towards Intergovernmental Balance of Power in Zimbabwe. Opportunities, Challenges and Critical Success Factors, 20(1.1) IOSR Journal OF HuMANITIES AND SOCIAL SCIENCE $42-48$ (2015).

${ }^{3} \mathrm{~B}$. Inyang, Contending Issues in the Management of Intergovernmental Relations in the Nigerian Federal Administration System, 5(3) MEDITERRANEAN Journal OF Social SCIENCES 226-233 (2014).

${ }^{4}$ T. A. Olaiya, Federalism and Intergovernmental Relations in Africa: Retrospect and Prospects from Nigeria, 5(2) Public Administration ResEARCh 87-102 (2016).
} 
According to them, the need for forming a government in itself is predicated on the "evils" of human nature. They argue that:

If men were angels, no government would be necessary. If angels were to govern men, neither external nor internal controls on government would be required. In framing a government which is to be administered by men over men, the great difficulty lies in this: you must first enable the government to control the governed; and in the next place oblige it to control itself. ${ }^{5}$

Similarly, intergovernmental relations can both exist within a federal structure and as well a unitary system of government. ${ }^{6}$ This shows that the clamour that intergovernmental relations are only associated with the federal system should be discarded when we remember the Livingstonian definition of federalism which says that "... Federalism is not an absolute but a relative term; there is no identifiable point at which a society ceases to be unified and becomes diversified". ${ }^{7}$ In a unitary state, intergovernmental relations would be referred to as the interactions between the national government and the sub-national governments. However, the constitutional allocation of governmental functions between federal and regional governments in a federal system is absent. It is the central government that determined which functions are allocated to the sub-national governments. ${ }^{8}$

In a federal system like Nigeria, local governments are closed to the people. Hence, local governments can complement the economic activities of other levels of government. ${ }^{9}$ This shows that local government occupies a central position in the socio-economic and political development. In fact, local government is vested with certain powers and enormous responsibilities. The reason for this is quite obvious, local government deals with the system of governance at the grassroots level, there is no doubt about the tremendous influence which the local government can exert on the general life pattern of the people at the grassroots levels where the bulk of the population resides. As a result, the majority of the citizenry are intimately affected by the activities of the various local governments on a daily basis. ${ }^{10}$

\footnotetext{
${ }^{5}$ Ibid.

${ }^{6}$ J. A. Bamgbose, Intergovernmental Relations and Political Opposition in Nigeria's Fourth Republic (1999-2004), 1(1) OZEAN JOURNAL OF SOCIAL SCIENCES 75-89 (2008).

${ }^{7}$ M. L. Bello, Intergovernmental Relations in Nigeria: An Assessment of Its Practice at the Local Government Level, 4(1) JOURNAL OF POVERTY, INVESTMENT AND DEVELOPMENT 66-76 (2016).

${ }^{8}$ Ibid.

${ }^{9}$ J. O. Fatile \& K. D. Adejuwon, Intergovernmental Financial Transfer and Socio-Economic Development at the Grassroot Level: An Empirical Study of Selected Local Governments in Lagos State, Nigeria, 5(2) INTERNATIONAL JOURNAL OF ADVANCED STUdies IN BUSINESS STRATEGIES AND MANAGEMENT 61-77 (2017).

${ }^{10}$ Ibid.
} 
Based on the above, the paper takes a cursory look at the place of local government in IGR with specific reference to South Africa and Nigeria. This paper beams its searchlight on the nature, character and the operation of IGR in federal and unitary states. This is necessary in order to understand IGR in different system of government and across national boundaries. Comparative perspective affords the opportunity to learn, from both differences and similarities, what the possible consequences of perusing particular paths in the development of IGR might be. ${ }^{11}$ South Africa and Nigeria are viewed as two of the Africa's most powerful nations. The reason for this is that both nations have played, and continue to play, prominent roles about pushing the African agenda on international platforms. The paper highlights issues for consideration in the management of intergovernmental relations in the unitary system as well as in the federal system of government. These two countries have been selected as they provide different governance systems, regarding the model of state organisation adopted. ${ }^{12}$

\section{LOCAL GOVERNMENT AND INTERGOVERNMENTAL RELATIONS: CONCEPTUAL ANALYSIS}

Local government is the involvement of grassroots people in the provision of social and economic amenities to the local areas. It is based on the principle that local problems and needs can be understood by the people of the locality better than by Central or State government. ${ }^{13}$ Also, local government is a political authority set up by a nation or state as a subordinate authority for the purpose of dispersing or decentralizing political power. $^{14}$

Local government can also be defined as a public organization, authorized to decide and administer a limited range of public policies within relatively small territory which is a subdivision of a regional or national government. ${ }^{15}$

\footnotetext{
${ }^{11}$ R. Kalema, Intergovernmental Relations in South Africa: A Comparative Analysis, A Paper Delivered at a Conference on Provincial Government in South Africa, held on August 16-18, 2000 at Holiday Inn Garden Court Umtata, South Africa (2000).

${ }^{12}$ Ibid

${ }^{13}$ D. Arowolo, Local Government Administration and Challenges of Rural Development in Nigeria, 2008, accessed online from www.articlebase.com on October 21, 2017.

${ }^{14}$ E. O. Awa, The Theory of Local Government, XV(1\&2) QUARTERLY JOURNAL OF ADMINISTRATION (October/January 1981).

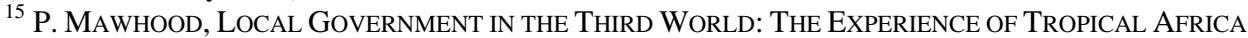
(London: John Wiley and Sons 1993).
} 
From the above definitions, it is clear that local governments are local entities, with defined territories, discretionary power, functions, responsibilities and, most importantly, autonomy. In principle, local governments are created with the expectation that its administrative and political officers will exert influence and control the decision-making process at the grass root level without interruptions from higher tiers of government.

Intergovernmental relations encompass all the complex and interdependent relations among various spheres of government as well as the coordination of public policies among national, provincial and local governments through programme reporting requirements, grants-in-aid, the planning and budgetary process and informal communication among officials. ${ }^{16}$ Similarly, intergovernmental relations is an interacting network of institutions at national, provincial and local levels, created and refined to enable the various parts of government to cohere in a manner which is appropriate to its institutional arrangements. ${ }^{17}$

Intergovernmental relations are the mutual relations and interactions between government institutions at horizontal and vertical levels. ${ }^{18}$ Intergovernmental relations refer to the political ethics commonly used to describe the interactions between the different levels of government within the state. ${ }^{19}$ IGRs are important interactions occurring between governmental institutions of all types and in all spheres. ${ }^{20}$ While Obi ${ }^{21}$ sees intergovernmental relations as the complex patterns of interactions, cooperation and inter-dependence between two or more levels of government.

It becomes clear from the above definitions that the nature of the interaction between different spheres of government constantly varies in terms of the degree of cooperation, depending on the dynamics of the system and the role-players involved at any given time and in accommodating and managing interdependence, geographical and social diversity, as well as on going comprehensive transformation.

\footnotetext{
${ }^{16}$ W. Fox \& I. H. Meyer, Public Administration Dictionary (London: Juta and Company Ltd. 1995).

${ }^{17}$ D. S. WRight, Understanding InTERGOVERnMENTAL RELATIONS (London: Brooks/Cole Publishers Inc. 1988).

${ }^{18}$ G. VAn DeR WaldT \& D. F. P. Du Toit, Managing for Excellence in the Public Sector, (Kenwyn: Juta 1997).

${ }^{19}$ L. AdAmolekun, Public Administration in Africa (Lagos: Spectrum Books Nigeria Ltd. 2002).

${ }^{20}$ W. A. ANDERSON, INTER-GOVERNMENTAL RELATIONS IN THE REVIEW (Minneapolis: University of Minnesota Press 1960).

${ }^{21}$ V. O. A. Obi, Modern Local Government Practice in Nigeria (Enugu: Cecta (Nig) Limited 2001).
} 


\section{THEORETICAL FRAMEWORK}

For the purpose of our analysis in this paper decentralisation theory is considered appropriate. The theory focuses on situations where different levels of government provide adequate levels of outputs of public goods "for those goods whose special patterns of benefits are encompassed by the geographical scope of their jurisdictions". ${ }^{22}$ Decentralization theory is based on the philosophy that sub-national governments in the federation must be given power over their own life and development. ${ }^{23}$ While Muraina ${ }^{24}$ affirms that decentralisation would make the local governments more competent in the management of their affairs.

The major shortcoming of decentralisation theory is that it can lead to problems such as soft-budget constraints, macroeconomic instability, clientelism, and enlargement of bureaucracies. Notwithstanding the highlighted weaknesses associated with decentralisation theory, relevant in explaining the dynamics of intergovernmental relations in federal and unitary states, in this case Nigeria and South Africa, respectively.

\section{METHODOLOGY}

The paper adopts the qualitative research approach. It draws its arguments basically from secondary data including existing legal frameworks and other related policies, textbooks, journals articles and other publications.

\section{THE NATURE OF INTERGOVERNMENTAL RELATIONS IN SOUTH AFRICA}

Intergovernmental relations have become an integral part of South African constitutional, political and administrative theory and practice. While all three spheres of government had to find their feet in the new democratic dispensation, "intergovernmental relations" has become synonymous with cooperation, consultation and coordination of governmental activities. ${ }^{25}$ IGR arose under the interim constitution with the creation of three spheres of government at national, provincial and local

\footnotetext{
${ }^{22}$ O. M. Ikeanyibe, Three Tier Federative Structure and Local Government Autonomy in Brazil and Nigeria, 5(15) MEDITERRANEAN JouRnal OF SOCIAL SCIENCE 559-569 (2014).

${ }^{23}$ J. K. Nyerere, FreEdOM AND DeVElopment (Dar Se Salam Oxford University Press 1972).

${ }^{24}$ A. O. Muraina, Local Government Finance in Nigeria: A Case Study of Iwo Local Government Area of Osun State, 6(6) Public Policy And Administration Research 52-64 (2015).

${ }^{25} \mathrm{~N}$. Malan, Intergovernmental Relations and Co-operative Government in South Africa: The TenYear Review, 24(2) PoliteiA 226-243 (2005).
} 
level. ${ }^{26}$

In South Africa, as unitary as it is, the executive is kept in checking by watchdogs such as the Public Protector and the Constitutional Court, hence placing the constitution at the forefront of the democracy since the constitution is used as a reference. The constitution allows provinces to be governed through their provincial legislature and furthermore grants the power to the provinces to confer legislative power to municipal councils. ${ }^{27}$

In the South African context, intergovernmental relations are intended to promote and facilitate cooperative governance and decision-making by ensuring that policies and activities across all government spheres are geared towards the delivery of services to meet the needs of communities in an effective way. To achieve this, the South African government has established intergovernmental structures, procedures, and toolkits. ${ }^{28}$ The birth of democracy in 1994 provided a window of opportunity for South Africa to change the development path of the country. The South African government realised that the ultimate goal of any state is to advance the welfare of the population and that this can be obtained through the promotion of intergovernmental relations and cooperative government. ${ }^{29}$

In South Africa, although the IGR system evolved amidst a centralised system that sought only to oversee security and protect the rights of a minority group using various governmental systems, it has gradually moved over the years toward a decentralised and devolved democratic system. The constitution of the Republic of South Africa, Act 108 of 1996 (Chapter 3) provides for an intergovernmental relations system that seeks to improve coordination and alignment.

The 1996 South African Constitution has been hailed as "a masterpiece which sought to advance service delivery through intergovernmental relations which would ensure coordinated and aligned government activities". ${ }^{30}$ The Constitution creates a system of government based on the three spheres of government: national, provincial and local government. Each has legislative and executive powers within its functional area, although the bulk of these powers are exercised concurrently between national and provincial government or devolved to local government. These

\footnotetext{
${ }^{26}$ M. K. Moosa, Long-Run and Short-Run Demand for Oil by Developing Countries: An Empirical Analysis, 22(1) OPEC ENERGY REVIEW 1-12 (1998).

${ }^{27}$ The Constitution of South Africa (2003).

${ }^{28}$ T. Edwards, Key Challenges of Improving Intergovernmental Relations at a Local Sphere: A Capacity Building Perspective, 43(3.1) Journal of Public Administration 89-98 (2008).

${ }^{29}$ N. Malan, Op. Cit. 2005.

${ }^{30}$ I. U. Ile, Strengthening Intergovernmental Relations for Improved Service Delivery in South Africa: Issues for Consideration, 7(1) JOURNAL OF US-CHINA ADMINISTRATION 51—57 (2010).
} 
spheres of government are not independent of each other; rather they are dependent and interrelated yet functionally distinctive. Each sphere of government is specifically directed by the Constitution, among other things, to preserve peace, the national unity and the indivisibility of the Republic of South Africa. ${ }^{31}$

South Africa has an intergovernmental system that is based on the principle of cooperation between the three spheres of government-local, provincial and national. While responsibility for certain functions is allocated to a specific sphere, many other functions are shared among the three spheres. The Chapter 3 of the 1996 South African Constitution describes the three spheres as being "distinctive, interdependent and interrelated" and enjoins them to "cooperate with one another in mutual trust and good faith". The constitution stresses that the relationship between the spheres should be cooperative rather than hierarchical. The constitutional relationship between the three spheres of government in South Africa emanates from three successive comparative constitutional dispensations. The Constitutional relationship as observes by Msase ${ }^{32}$ establishes guiding principles for effective and efficient execution of public policies by state departments or institutions that are responsible for the rendering of services. Also, the constitutional relationship between the three spheres of government is more or less relative as opposed to absolute sociopolitical and economic relations.

The principles of co-operative government and intergovernmental relations recognise the interdependence of the three spheres of government in South Africa which are distinctive and interrelated and place a duty on the spheres of government to respect each other's powers, functions and institutions and to inform each other of new policies. The formulation and implementation of these policies have to be consistent with the political, social, economic and sustainable development priorities of the democratic South Africa and also take into consideration the diverse nature of the state. ${ }^{33}$

\section{LOCAL GOVERNMENTS AND IGRS IN SOUTH AFRICA}

The South African system of intergovernmental relations is complex

\footnotetext{
${ }^{31}$ Z. Titus, Keynote Address: Provincial Government in South Africa, paper delivered at a Conference on Provincial Government in South Africa, held on August 16-18, 2000 at Holiday Inn Garden Court Umtata, South Africa (2000).

${ }^{32} \mathrm{~S}$. Msaseni, The Impact of Constitutional Relationships between the Three Spheres of Government: The South African Perspective. A paper delivered at a Conference on Provincial Government in South Africa, held on August 16-18, 2000 at Holiday Inn Garden Court Umtata, South Africa.

${ }^{33}$ N. Malan, Op. Cit. (2005).
} 
and continues to evolve as better modes of cooperation and coordination among different spheres of government. The South African constitution of 1997 dedicated considerable attention to local government.

The process of local government democratisation in South Africa is first founded in the Constitution. Local government is made up of 283 municipalities in South Africa which are based on three constitutional categories: six metropolitan municipalities, 46 district municipalities and 231 local municipalities. Local government is constitutionally recognised along with provincial and national government as a sphere of government and has an entrenched though the limited degree of autonomy. As such, it is one of the building blocks of South Africa's decentralised state structure and may still become its fundamental building block. ${ }^{34}$

Olowu ${ }^{35}$ states that the constitution recognises and articulates three spheres of institutional action, thus rendering national, provincial and local governments as equal, separate and autonomous though within the framework of a unitary arrangement. Also, the relationship is cooperative, not hierarchical and thirdly it establishes the principle of subsidiarity. In addition to the functions of local government-involving public infrastructures - streets, refuse and Streetlights and those requiring user fees such as electricity, water and sanitation-national and provincial governments were to transfer functions and revenues to local governments. Local governments have access to revenues and also manage their own personnel. It is significant that like in Nigeria with extensive decentralist constitutions-fiscal flows from the South African national government does not go through the provincial governments. ${ }^{36}$

The South African intergovernmental government system has significant functions decentralised to the local government level. While in many countries the relationship among levels of government is strictly hierarchical, the situation in South Africa is quite different. The local government sphere operates within the policy and funding parameters set primarily by national government. In comparison with international practice, local government has been given considerable constitutional recognition.

The 1996 Constitution further enhanced the status of local government. As a distinctive sphere of government, alongside national and provincial governments, it was no longer subject to their absolute control. The

\footnotetext{
${ }^{34}$ C. Steytler, Local Government in South Africa: Entrenching Decentralized Government, in THE Place And Role of Local Government in Federal Systems (C. Steytler ed., Johannesburg: Konrad-Adenauer-Stiftung 2005).

${ }^{35}$ D. Olowu, The Constitutionalization of Local Government in Developing Countries-Analysis of African Experiences in Global Perspective, 3 BeIJING LAW REVIEW 42-50 (2012).

${ }^{36}$ Olowu, Op. Cit. (2012).
} 
enhanced status of local government is seen in some provisions. The constitution spelt out the relationship of the spheres of governments as distinct, interdependent and interrelated. It further requires the three spheres of government to function within a framework known as principles of cooperative government. ${ }^{37}$ The Constitution of the Republic of South Africa (1996) emphasises the duty of local government to address the basic needs of communities, to provide services and to engage in social and economic development.

\section{AN OVERVIEW OF INTERGOVERNMENTAL RELATIONS IN NIGERIA}

In Nigeria, like in most federal states, the relationship between tiers and arms of government is problematic. Since the return to civil rule in 1999, Nigeria has witnesses several intergovernmental conflicts over jurisdictional power, while the federal structure has come under attack in these conflicts. ${ }^{38}$ The general tendency of federal states becoming heavily centralised and the overbearing nature of the central government most especially the executive had over the year heightened inter and intra governmental relations conflict in the country. ${ }^{39}$ This has influenced the behavior of the political elite, which account for the weakness of intergovernmental institutions in Nigeria. $^{40}$

Intergovernmental relations in Nigerian federation entails formal allocation of powers both vertical and horizontally among various levels of government. In this relationship, local government is seen as a third tier or level of government with the power to transform their areas of jurisdiction through good governance. ${ }^{41}$

The evolution of fiscal federalism in Nigeria can be properly situated within the different political, and constitutional, social, cultural and economic developments which have in turn influenced the nature and

\footnotetext{
${ }^{37}$ J. Kuye, International Perspectives on the Allocation of Powers between the Tiers of Government: The Case of Nigeria, A paper delivered at a Conference On Provincial Government In South Africa, held on August 16-18, 2000 at Holiday Inn Garden Court Umtata, South Africa.

${ }^{38}$ J. O. Fatile \& K. D. Adejuwon, Intergovernmental Fiscal Relations in Nigeria, 6(4) JouRnAL OF SOCIAL AND POLICY ISSUES 91-99 (2009).

${ }^{39}$ S. H. Abidoye, The Nature of the Governmental Relationship (Inter and Intra) in Nigeria's FifteenYear-Old Democratisation, 20(7) IOSR JOURNAL OF HuMANITIES AND SOCIAL SCIENCE 54-58 (2015).

${ }^{40}$ J. O. Fatile \& K. D. Adejuwon, Intergovernmental Relations in Nigeria; An Appraisal of the Involvement of Local Government, 8(3) THE CONSTITUTION: A JOURNAL OF CONSTITUTIONAL DEVELOPMENT 83-101 (2008).

${ }^{41}$ E. I. Enefiok \& N. A. Ekpe, The Role of Ministry of Rural Development in the Promotion of Community Development in Akwa Ibom State, Nigeria, DeVEloping CounTRY STUdies 2225-0565 (2014).
} 
character as well as the pattern of intergovernmental relations in Nigeria. ${ }^{42}$ Though, the adoption of a federal polity is a political design to absorb conflicting issues in every polity, the advent of May 29, 1999, which gave birth to Nigeria's Fourth Republic witnessed the most conflicting political opposition ever experienced in Nigeria's polity as the various tiers of government engaged in competitive rather than co-operative relations thereby endangering the cordial relations expected among these governments. The provisions of the 1999 Constitution have in all, emphasized vertical interaction among the three levels of government rather than horizontal relationships. ${ }^{43}$ The importance of intergovernmental relations in a federal polity is to enable unity and cooperation to prevail. ${ }^{44}$

The IGR practice in the democratic dispensation since 1999 has been characterized by continued federal dominance and state dependency. There have been rumblings among the various components of government over power limitations and policy implementation. There have been resistances by oppositional states to the wide constitutional mandate of the central government. And this has made intergovernmental relations fundamentally problematic and conflictual rather than harmonious in Nigeria. ${ }^{45}$

\section{LOCAL GOVERNMENTS AND IGRS IN NIGERIA}

It is generally believed that the local government system anywhere in the world should offer the best approach to sustainable development in the respective country in which they are situated. This belief is premised on the fact that local governments are closer to the people and as such in a better position to bring development to them. However, rather unfortunately, there have been constant reports of slow and poor performance of this tier of government in many parts of in developing countries and Nigeria in particular. ${ }^{46}$ It has been observed that one of the nagging problems of Nigeria's federalism is the persistent failure to grant fiscal autonomy to local government as a third tier of government. The issue of autonomy and

\footnotetext{
${ }^{42}$ E. O. Oni, Intergovernmental Fiscal Relations in Nigeria's Fourth Republic: Issues and Challenges. 1(2) COVEnANT University Journal of Politics AND InTERNATIONAL AFFAirs 213-234 (2013).

${ }^{43}$ S. H. Abidoye, Op. Cit. (2015).

${ }^{44}$ A. P. Chiamogu, V. C. Onwughalu \& U. P. Chiamogu, Politics of Inter-Governmental Relations in Nigeria: An Appraisal of Current Issues, 2(11) InTERNATIONAL Journal OF ASIAN SOCIAL SCIENCE 1892-1905 (2015).

${ }^{45}$ E. O. Oni, Intergovernmental Fiscal Relations in Nigeria's Fourth Republic: Issues and Challenges. 1(2) COVEnANT University Journal of Politics AND InTERnATIONAL AFFAirs 213-234 (2013).

${ }^{46}$ F. F. Nchuchuwe \& K. D. Adejuwon, Making Local Government Efficient and Effective For Nigeria's Development in the $21^{\text {st }}$ Century, 4(1) INTERNATIONAL JOURNAL OF DEVELOPMENT STUdies 1-16 (2008).
} 
control of local government constitute a great cog in the wheel of progress of local government in Nigeria. Lack of fiscal autonomy weighs heavily against the progress and growth of local government as a third tier of government in Nigeria and hamper its efforts at providing sustainable development at the grassroot level. ${ }^{47}$ This problem has been provoked by a number of factors, including "over dependence" on statutory allocations from both the state and federal governments, deliberate tax evasion by the local citizenry, creation of non-viable local government areas, differences in the status of local governments in terms of rural-urban dimension, and inadequate revenue and restricted fiscal jurisdiction.

There is no gain saying the fact that in Nigeria, the degree of decentralization of expenditure is higher than the degree of decentralization of revenue thereby causing a great divergence between sources of revenue and functional expenditure obligations in the local government. This means that there is a lack of the necessary symmetry, hence the problems on noncorrespondence or vertical fiscal imbalance. ${ }^{48}$

The situation of local governments in Nigeria under the 1999 Constitution is complex and confusing. Although the constitution guarantees the existence of a democratically elected local government system, like the 1976 constitution, it gives the states the responsibility to handle issues of organisation and structure of local governments in Nigeria. ${ }^{49}$ The provision of $20 \%$ for local governments in the revenue allocation formula of the federation's account remains a tragic reminder of the lack of political will to appropriately address the problem of local representations and effective delivery of services. ${ }^{50}$ The state's government action towards the local government since the advent of democracy in 1999 had resulted in unpleasant relations between the states and local government. ${ }^{51}$

In describing the place of Nigerian local government in IGR,

\footnotetext{
${ }^{47}$ F. F. Nchuchuwe \& K. D. Adejuwon, Inter-Governmental Fiscal Relations and Local Government in Nigeria: Issues and Prospects, III(X) SCIENTIFIC ReSEARCH Journal 31-37 (2015); D. Aworawo \& N. E. Akpan, Local Government Administration, in IsSUES IN NIGERIAN GovERNMENT AND Politics (A. Osuntokun et al. eds, Ibadan: Rex Charles Publication 2003).

${ }^{48}$ S. T. AKINDELE \& D. OlaOPA, FisCAL FEDERALISM AND LOCAL GOVERNMENT FinANCE IN NigeRiA (Ibadan: Spectrum Book 2002).

${ }^{49}$ J. Fatile \& A. Majekodunmi \& A. Oni \& D. Adejuwon, IssuEs In Public Administration AND Local Government: The Comparative Approach (Lagos: Concept Publications 2013).

${ }^{50} \mathrm{~B}$. W. Shiyanbade, Interrogating the Revenue Allocation in Intergovernmental Relations, Fiscal Federalism and Local Government Finance in Nigeria, 6(11) INTERNATIONAL JOURNAL OF HUMANITIES AND SOCIAL SCIENCE 99-107 (2016).

${ }^{51}$ P. C. Amobi, C. O. Vincent \& P. C. Uchechukwu, Politics of Intergovernmental Relations in Nigeria: An Appraisal of Current Issues, 2(11) INTERNATIONAL JOURNAL OF ASIAN SOCIAL SCIENCE 1892-1905 (2014).
} 
Adewunmi ${ }^{52}$ asserts that "local government is a state subject". This reference is not just subjugation but explains the kind of relationship that exists between the government of the federation and the state government in one hand and the Local Government on the other. The nature, pattern and character of the relationship between local government and other tiers of government in Nigeria are hierarchical. It is characterized by inclusive and arbitrary overlapping models. ${ }^{53}$

Therefore, it is appropriate to observe that intergovernmental relation between State and Local Government in Nigeria is a crude type of masterservant relationship. Any Chairman of Local Government that wants to do something independently outside the one dictated by the state executive will be frustrated and finally removed through the use of the state apparatus like the court, State House of Assembly or the concerned local government council will be used to impeach their council chairman.

\section{NATURE AND PATTERN OF INTERGOVERNMENTAL RELATIONS IN SOUTH AFRICA AND NIGERIA: A COMPARISON}

This paper is located between South Africa (unitary state) and Nigeria (federal state). It is important to note from the above that the degree of decentralisation in the form of unitarism and federalism varies from country to country as in the case of South Africa and Nigeria.

Given the important roles that South Africa and Nigeria play in their respective regions, the extent to which they can deliver services to their people could provide an opportunity for lessons to be learnt about successes as well as challenges. As observed by the United Nations Development Programme ${ }^{54}$ in order to bridge the gaps in democratic practice, one solution is to decentralize power to lower levels of government, bringing it closer to the people, but this requires strong structures and state capacities (intergovernmental relations) to control, monitor and evaluate various activities. The constitutional structure of South Africa may be compared with the constitutional structure of Nigeria in terms of the dividing of competencies between different tiers or spheres of government which in turn necessitates intergovernmental relations.

South Africa like Nigeria is a highly heterogeneous society. While

\footnotetext{
52 J. B. Adewumi, Central-Local Government Relations (Benin: Ethiope Publishing Corporation 1983).

${ }^{53}$ B. E. Awortu, Rethinking Local Government Administration in Nigeria, 3(4) AFRICAN JournAL OF SOCIAL SCIENCES 248-257 (2013).

${ }^{54}$ UndP, Human DEVELOPMENT REPORT 2002: DEEPENING DEMOCRACY IN A FRAGMENTEd World (New York: UNDP 2002).
} 
South Africa as a unitary state operates three spheres of government, Nigeria as a federal state operate three tiers of government. In South Africa, for the achievement of governmental goals including cooperative government as proposed by the 1996 constitution of the Republic of South Africa, there is provision for an intergovernmental relations system that seeks to improve coordination and alignment. The Nigerian constitution of 1999, (chapter 1, part 1) pronounces the nation as a federation consisting of thirty-six states and a federal capital territory. Even though the Constitution of South Africa, being a unitary state, differs from the constitutional dispensation of Nigeria, comparisons can still be made between intergovernmental relations in the two countries because of the number of federal elements enshrined in the 1996 Constitution of the Republic of South Africa and the 1999 Constitution of the Federal Republic of Nigeria. The influence that the separation of powers has on intergovernmental relations in South Africa, as in Nigeria, emphasises the strong political component in intergovernmental relations in the two countries. The political nature of intergovernmental relations is also strengthened by the existence of some political parties in both states.

The three tiers of government and the distribution of power in Nigeria can be compared to the three spheres of government in South Africa. This distribution of power in both states influences the legislative, executive and administrative intergovernmental relations. Fundamentally, the local governments in Nigeria are not efficiently financed. Unlike what is obtainable in South Africa where local authorities are given the discretion to engage in generating revenues. In the Nigerian context, the federal and state governments hijack a bulk of resources meant for local administration as well as powers for the local authorities to generate revenue. Consequently, this situation as observes by $\mathrm{Alo}^{55}$ thus ensured a high dependency on federal and state allocations which are not efficient to satisfy the needs of the 774 local government areas in the country.

Intergovernmental relations in Nigeria are mainly informal and seldom structured and may also be compared with the informal nature of intergovernmental relations in South Africa where interaction between national and provincial departments occurs using e-mail, fax, memorandums or personal visits. The opening of informal channels of communication may, however, contribute a lot towards resolving the conflict between different spheres of government.

The federal system in Nigeria allows for the Federal and State Governments to both have distinct and concurrent competencies and, as in

\footnotetext{
${ }^{55}$ E. N. Alo, Fiscal Federalism and Local Government Finance in Nigeria, 2(5) WORLD JournAL OF EDUCATION 19-27 (2012).
} 
South Africa, it may have a direct influence on legislative intergovernmental relations in the two countries. In South Africa, the national government may intervene in the action of provincial governments in certain instances just as the Federal Government in Nigeria may override decisions made by the State Governments.

\section{CONCLUSION}

Governments around the world have come to the realisation that in order to deliver effective services to the people, there is a need for collaboration, cooperation and coordinated effort among different levels of government. South Africa and Nigeria have not been an exception to this movement towards coordinating efforts to ensure the efficient delivery of services to the citizens. Intergovernmental relations have been the pillar of the efforts to ensure a coordinated response to the challenges facing people especially at the grassroots.

Intergovernmental relations are intended to promote and facilitate cooperative government and decision-making by ensuring that policies and activities across all spheres encourage service delivery to meet the needs of citizens in an effective way. ${ }^{56}$ This paper has shown that intergovernmental relations in South Africa and Nigeria have steadily grown in popularity as a means employed by governments in delivering services to the citizen.

There is no doubt that local government councils are in the best position to play a major role in the grassroots development of our society. As the nearest government to the people, much is expected of it hence the need for an effective and result-oriented administration through effective intergovernmental relations.

There may be different benefits and challenges in the management of IGRs in various countries. However, some critical elements that underpin the nature and place of local governments in South Africa and Nigeria have been identified and discussed in this paper. These will strengthen local government systems, enable the achievement of the desired goals, create synergy among spheres of government and bring about the effective and efficient service delivery at the grassroots. In the final analysis, it must also be borne in mind that neither a constitution nor an efficient system of IGR can guarantee political stability in a country. While sound IGR is not a sufficient condition for a stable democracy, their absence is, however, likely to aggravate the situation.

\footnotetext{
${ }^{56}$ T. Edwards, Key Challenges of Improving Intergovernmental Relations at a Local Sphere: A Capacity Building Perspective, 43(3.1) Journal of Public AdMinistration 89—98 (2008).
} 